\title{
Long-term ticagrelor monotherapy versus standard dual antiplatelet therapy followed by aspirin monotherapy in patients undergoing biolimus-eluting stent implantation: rationale and design of the GLOBAL LEADERS trial
}

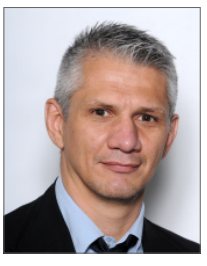

Pascal Vranckx ${ }^{1}, \mathrm{MD}, \mathrm{PhD}$; Marco Valgimigli², MD, PhD; Stephan Windecker ${ }^{3}$, MD; Philippe Gabriel Steg ${ }^{4,5}$, MD; Christian Hamm ${ }^{6}$, MD, PhD; Peter Jüni ${ }^{7}, \mathrm{MD}$;

Hector M. Garcia-Garcia ${ }^{2,8}, \mathrm{MD}, \mathrm{PhD}$; Gerrit Anne van $\mathrm{Es}^{8}, \mathrm{PhD}$; Patrick W. Serruys ${ }^{5 *}, \mathrm{MD}, \mathrm{PhD}$; on behalf of the GLOBAL LEADERS Study Group

1. Hartcentrum Hasselt, Hasselt, Belgium; 2. Erasmus MC, Rotterdam, The Netherlands; 3. Bern University Hospital, Bern, Switzerland; 4. Université Paris Diderot-Sorbonne Paris Cité, DHU-FIRE, AH-HP and INSERM U-1148, Paris, France; 5. Imperial College London, London, United Kingdom; 6. Medical Clinic I, University of Giessen and Kerckhoff Heart and Thorax Center, University of Giessen, Bad Nauheim, Germany; 7. Institute of Social and Preventive Medicine, University of Bern, Bern, Switzerland; 8. Cardialysis, Rotterdam, The Netherlands

GUEST EDITOR: George Dangas, MD, PhD; Division of Cardiology, Mount Sinai Medical Center, New York, NY, USA; Cardiovascular Research Foundation, New York, NY, USA

This paper also includes supplementary data published online at: http://www.pcronline.com/eurointervention/107th_issue/204

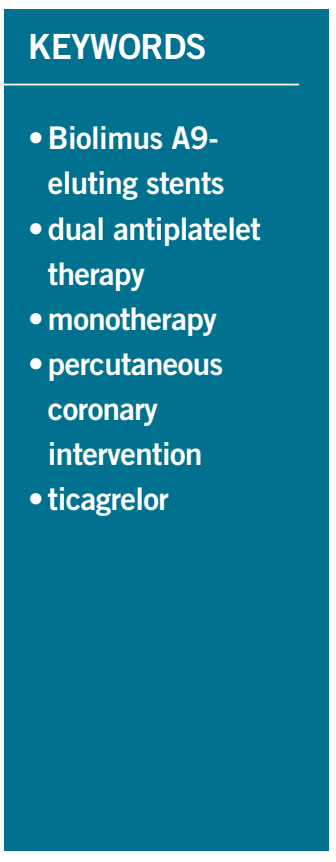

\begin{abstract}
Aims: The GLOBAL LEADERS trial is a superiority study in patients undergoing percutaneous coronary intervention, with a uniform use of Biolimus A9-eluting stents (BES) and bivalirudin. GLOBAL LEADERS was designed to assess whether a 24-month antithrombotic regimen with ticagrelor and one month of acetylsalicylic acid (ASA), compared to conventional dual antiplatelet therapy (DAPT), improves outcomes.

Methods and results: Patients $(\mathrm{n}>16,000)$ are randomised (1:1 ratio) to ticagrelor $90 \mathrm{mg}$ twice daily for 24 months plus ASA $\leq 100 \mathrm{mg}$ for one month versus DAPT with either ticagrelor (acute coronary syndrome) or clopidogrel (stable coronary artery disease) for 12 months plus ASA $\leq 100 \mathrm{mg}$ for 24 months. The primary outcome is a composite of all-cause mortality or non-fatal, new Q-wave myocardial infarction at 24 months. The key safety endpoint is investigator-reported class 3 or 5 bleeding according to the Bleeding Academic Research Consortium (BARC) definitions. Sensitivity analysis will be carried out to explore potential differences in outcome across geographic regions and according to specific angiographic and clinical risk estimates.
\end{abstract}

Conclusions: The GLOBAL LEADERS trial aims to assess the role of ticagrelor as a single antiplatelet agent after a short course of DAPT for the long-term prevention of cardiac adverse events, across a wide spectrum of patients, following BES implantation.

\footnotetext{
*Corresponding author: Centre for International Cardiovascular Health, National Heart \& Lung Institute (NHLI), Imperial
} College London, South Kensington Campus, London, SW7 2AZ, United Kingdom. E-mail: patrick.w.j.c.serruys@gmail.com 


\section{Background}

The optimum duration of dual antiplatelet therapy (DAPT) after coronary drug-eluting stent placement remains uncertain. Practice guidelines recommend DAPT for at least 12 months following drug-eluting stent (DES) implantation in patients with acute coronary syndromes (ACS), and for at least six months in patients with stable coronary artery disease (SCAD) in Europe ${ }^{1,2}$. The evidence base supporting the "at least 12 months recommendation" in ACS patients is weak, and some randomised controlled trials actually provide evidence suggesting that the risks of prolonging DAPT beyond six to 12 months outweigh the potential benefits ${ }^{3-6}$.

Conversely, recent trials on DAPT duration have shown a clear reduction in rates of stent thrombosis and major adverse cardiovascular events in patients free from bleeding or ischaemic events at 12 months who continued the DAPT regimen up to 30 months. While an increase in bleeding risk was a potentially anticipated finding, the observation of a possible increase of non-cardiovascular mortality in patients prolonging DAPT beyond 12 months remains a matter of concern ${ }^{7-9}$. For more than a decade, the mainstay of DAPT has been the combination of the weak cyclo-oxygenase-1 inhibitor acetylsalicylic acid (ASA), and clopidogrel. However, the inherent limitations of clopidogrel are well recognised, including a slow onset of action and a variable response $\mathrm{e}^{10-13}$. Prasugrel and ticagrelor provide superior protection against ischaemic adverse events compared with clopidogrel in patients following an ACS undergoing percutaneous coronary intervention (PCI $)^{14-16}$. Notwithstanding this, both drugs incur an increased risk of spontaneous bleeding. As of today, these drugs have not been tested in patients undergoing elective $\mathrm{PCI}$ for SCAD, or as monotherapy (i.e., without ASA).

Ticagrelor is a reversible oral $\mathrm{P} 2 \mathrm{Y}_{12}$ receptor antagonist that does not require metabolic activation ${ }^{17}$. The inter-individual variability of platelet inhibition is low ${ }^{17}$. In the Platelet Inhibition and Patient Outcomes (PLATO) trial there was a hint of an attenuation of the treatment effect of ticagrelor by an ASA maintenance dose above $150 \mathrm{mg}$ once daily ${ }^{18,19}$. Given the fact that strong P2 $\mathrm{Y}_{12}$ receptor inhibition may also provide inhibition of the COX-1 pathway, it remains possible that ticagrelor monotherapy maintains efficacy compared to the combined use of aspirin and ticagrelor, while improving safety (i.e., a reduction of spontaneous/gastrointestinal bleeding $)^{20}$.

Finally, during long-term follow-up, optimisation of secondary prevention and overall medical management are at least as important as the selection of which stent to use $\mathrm{e}^{21-24}$. A potent consistent and reversible $\mathrm{P} 2 \mathrm{Y}_{12}$ receptor antagonist such as ticagrelor may provide superior efficacy with similar or improved safety compared to the current standard regimen ${ }^{24}$.

\section{Study objectives}

GLOBAL LEADERS (ClinicalTrials.gov, NCT01813435) was designed to determine the benefits and risks of an antithrombotic regimen using ticagrelor combined with acetylsalicylic acid (ASA) for one month and alone for 23 months, compared to conventional
DAPT in patients on bivalirudin undergoing biolimus-eluting stent implantation.

Substudies are planned to enhance understanding of the treatment effects and refine modelling of outcomes (Online Appendix 1). The SYNTAX score (SX score) for each patient will be calculated by scoring all coronary lesions with a DS $\geq 50 \%$, in vessels $\geq 1.5 \mathrm{~mm}$, using the SX score algorithm (available at www.syntaxscore.com $)^{25}$. The GRACE risk score at index admission will be calculated for all patients suffering an acute coronary syndrome $(\mathrm{ACS})^{26}$.

\section{Study oversight}

GLOBAL LEADERS is an investigator-initiated and scientifically driven trial sponsored by the European Clinical Research Institute (www.ECRI-trials.com), a non-profit organisation which received funding from Biosensors (Morges, Switzerland), AstraZeneca (Mölndal, Sweden), and The Medicines Company (Parsippany, NJ, USA) for the study conduct (Online Appendix 2).

The academic members of the steering committee designed the trial in collaboration with an independent statistician (Peter Jüni, Bern, Switzerland). The steering committee, together with an operations committee and academic representatives from ECRI, will oversee the medical, scientific, and operational conduct of the study. The steering committee members are responsible for the reporting of the results and the drafting and editing of this and forthcoming manuscripts.

An independent data and safety monitoring board (DSMB) monitors patient safety on an ongoing basis and has access to unblinded data.

Site management and monitoring is performed by Cardialysis in Europe and Theorem in Brazil, Canada, and Singapore. Angiographic data (SYNTAX score) and 12-lead ECGs (postindex PCI before discharge, three-month and two-year followup) will be analysed off-line by an independent core laboratory (Cardialysis, Rotterdam, The Netherlands).

Data cleaning and preparation will be performed by the Cardialysis data management group. After database lock, the database will be housed for statistical analysis at the Clinical Trials Unit (Department of Clinical Research, University of Bern, Bern, Switzerland).

The study adheres to the ethical principles of the Declaration of Helsinki, to specifications of the International Conference of Harmonization, and to Good Clinical Practice. The study underwent approval by an ethics committee or institutional review board at each site.

\section{Study design}

The GLOBAL LEADERS trial is designed as a multicentre, multinational, open-label superiority randomised clinical trial. Patients will be randomised before intervention to the experimental or reference DAPT antithrombotic strategy (Figure 1) in a 1:1 ratio using a web-based system with random, permuted blocks and stratified by site and clinical presentation (SCAD versus ACS). 


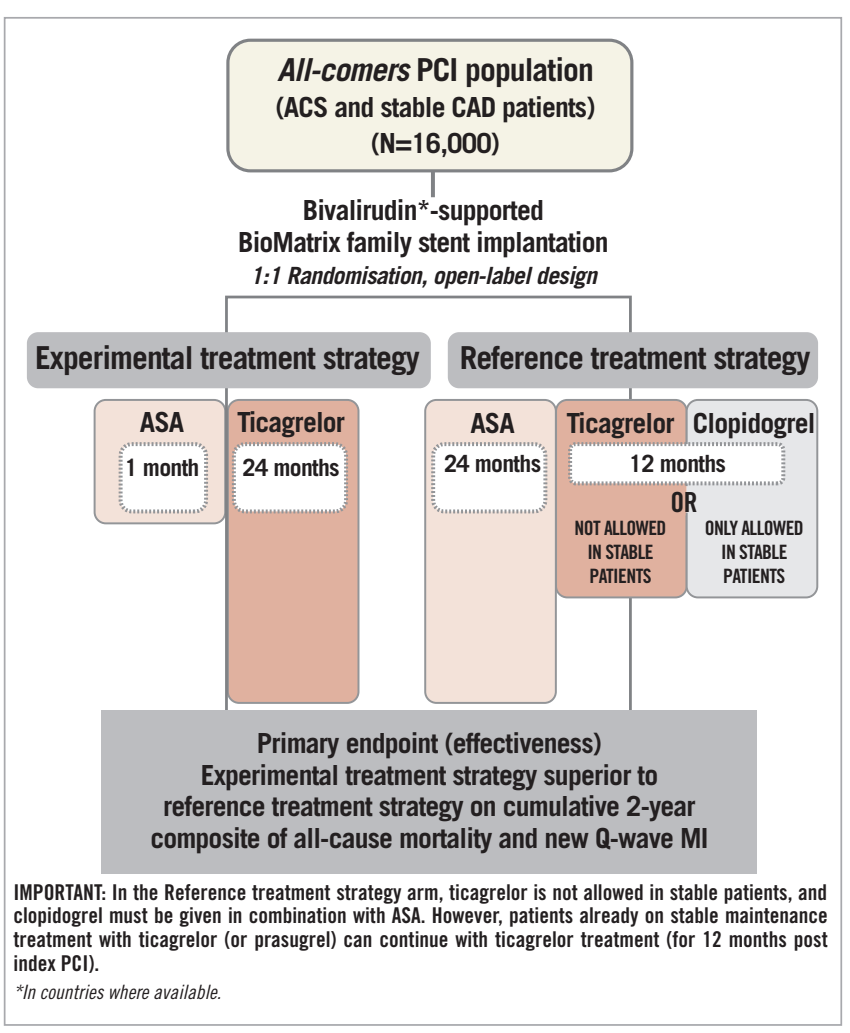

Figure 1. GLOBAL LEADERS study design diagram.

Coronary anatomy is to be known in order to assess eligibility for PCI before randomisation in all patients. Multiple target vessel interventions are allowed either within the index procedure or as a pre-specified, staged (within three months following the index PCI) procedure. Randomised treatment continues for a minimum of two years post index PCI procedure in all patients (in case of a staged procedure, for up to two years after the initial stage of the index procedure). Outpatient study visits are scheduled at one, three (safety visit), six, 12, and 18 months after the index PCI procedure, with an end-of-treatment visit at 24 months.

\section{Patient population}

The GLOBAL LEADERS trial will enrol approximately 16,000 patients in more than 100 interventional cardiology sites in Europe, Asia, Brazil, Australia and Canada during a period of approximately 16-24 months. Inclusion and major exclusion criteria are shown in Table 1 and Table 2, respectively. According to the "all-comers" concept, there are no restrictions as to the number, severity, or location of lesions, or the number of stents

\section{Table 1. Inclusion criteria.}

Consecutive patients with the following inclusion criteria:

1 . Age $\geq 18$ years.

2. Patients with any clinical indication for $\mathrm{PCl}$.

3. Presence of one or more coronary artery stenoses of $50 \%$ or more in a native coronary artery or in a saphenous venous or arterial bypass conduit suitable for coronary stent implantation in a vessel with a reference vessel diameter of at least $2.25 \mathrm{~mm}$.
Table 2. Exclusion criteria.

\begin{tabular}{|c|c|c|}
\hline \multirow[t]{4}{*}{$\begin{array}{l}\text { Drug- } \\
\text { related }\end{array}$} & 1. & $\begin{array}{l}\text { Known intolerance to aspirin, } \mathrm{P}_{2} \mathrm{Y}_{12} \text { inhibitors, } \\
\text { bivalirudin, stainless steel or biolimus. }\end{array}$ \\
\hline & 2. & $\begin{array}{l}\text { Known intake of a strong CYP3A4 inhibitor (e.g., } \\
\text { ketoconazole, clarithromycin, nefazodone, ritonavir, } \\
\text { and atazanavir), as co-administration may lead to } \\
\text { a substantial increase in exposure to ticagrelor. }\end{array}$ \\
\hline & 3. & Use of fibrinolytic therapy within 24 hours of $\mathrm{PCl}$. \\
\hline & 4. & Known severe hepatic impairment. \\
\hline \multirow[t]{4}{*}{$\begin{array}{l}\text { Treatment- } \\
\text { related }\end{array}$} & 5. & $\begin{array}{l}\text { Planned CABG as a staged procedure (hybrid) } \\
\text { within } 12 \text { months of the index procedure. }\end{array}$ \\
\hline & 6. & $\begin{array}{l}\text { Planned surgery within } 12 \text { months of } \mathrm{PCl} \text { unless } \\
\text { dual antiplatelet therapy is maintained throughout } \\
\text { the peri-surgical period. }\end{array}$ \\
\hline & 7. & Need for oral anticoagulation therapy. \\
\hline & 8. & PCl for a priori known stent thrombosis. \\
\hline \multirow[t]{3}{*}{ Medical } & 9. & Known overt major bleeding. \\
\hline & 10. & Known history of intracranial haemorrhage. \\
\hline & 11. & $\begin{array}{l}\text { Known stroke from ischaemic or unknown cause } \\
\text { within last } 30 \text { days. }\end{array}$ \\
\hline \multirow[t]{3}{*}{ General } & 12. & Known pregnancy at time of randomisation. \\
\hline & 13. & Inability to provide informed consent. \\
\hline & 14. & $\begin{array}{l}\text { Currently participating in another trial before } \\
\text { reaching primary endpoint. }\end{array}$ \\
\hline
\end{tabular}

used. Key exclusion criteria are limited to study medication safety/ intolerance, stent component allergies, or planned need for surgery within the six months after the index procedure. Patients with ST-elevation ACS treated with fibrinolysis or patients in need of chronic anticoagulation are deemed not eligible.

\section{Treatment regimens and concomitant medications}

Patients are randomly assigned to either ticagrelor combined with ASA $\leq 100 \mathrm{mg}$ for one month followed by monotherapy for 23 months or standard DAPT with clopidogrel for 12 months plus ASA up to $100 \mathrm{mg}$ (SCAD patients), or ticagrelor standard treatment for 12 months plus ASA $\leq 100 \mathrm{mg}$ (ACS patients) followed by ASA monotherapy for the study duration (Figure 1). The use of clopidogrel is restricted to patients undergoing elective PCI for stable lesions (cardiac biomarker negative, no clinical signs and/or symptoms of ongoing myocardial ischaemia lasting $>20$ minutes).

DAPT is started as early as possible, and no later than two hours after the index procedure. Patients receiving at least one maintenance dose of ticagrelor or prasugrel will be allocated to a ticagrelor arm (either intervention or reference) upon randomisation. In the case of staged PCI or in case of unplanned reintervention (other than for definite stent thrombosis or ST-segment elevation myocardial infarction) in the study treatment arm, the 30-day treatment period with ASA will restart at the time of the staged procedure or reintervention.

Patients assigned to a ticagrelor arm who have not yet received a loading dose of ticagrelor or prasugrel, or who have received a prasugrel $60 \mathrm{mg}$ loading dose within five days prior 
to randomisation, but not continued thereafter with a daily 10 or $5 \mathrm{mg}$ maintenance regimen without interruption, will receive a loading dose of ticagrelor of $180 \mathrm{mg}$ (two $90 \mathrm{mg}$ tablets). Otherwise, a dose of ticagrelor of $90 \mathrm{mg}$ will be administered as the first dose. Patients assigned to clopidogrel who have not yet received a loading dose of clopidogrel or have not been taking clopidogrel or ticlopidine for $\geq 5$ days before randomisation will receive a $600 \mathrm{mg}$ loading dose and, otherwise, a maintenance dose of clopidogrel study drug as their first dose. For patients not previously having received ASA, a loading dose of $325 \mathrm{mg}$ is preferred (160-500 mg allowed).

In case of ticagrelor discontinuation due to adverse effects other than bleeding (i.e., atrioventricular block, dyspnoea), patients should be put on a standard dose of prasugrel in both study arms.

In case of definite stent thrombosis or ST-segment elevation myocardial infarction (STEMI), patients will no longer need to adhere to the study protocol-mandated medication regimen and will be treated according to best clinical practice.

Patients who require oral anticoagulation after randomisation should be treated according to local guidelines. Triple therapy should only be prescribed for the shortest necessary duration with frequent INR measurement (target INR 2-2.5), with clopidogrel becoming the default $\mathrm{P} 2 \mathrm{Y}_{12}$ inhibitor.

\section{Concomitant medication/stent}

The GLOBAL LEADERS trial demands uniform anticoagulation during the procedure and uniform stent platform use during the index procedure (including staged procedures) and any unplanned or intercurrent re-PCI.

In all patients, anticoagulation during the procedure will be accomplished with bivalirudin $\left(\right.$ Angiox $^{\circledR}$ or Angiomax ${ }^{\circledR}$; The Medicines Company, Parsippany, NJ, USA in the countries where the drug is approved) given as a bolus of $0.75 \mathrm{mg} /$ $\mathrm{kg}$ followed immediately by an infusion of $1.75 \mathrm{mg} / \mathrm{kg} / \mathrm{hr}$ for at least the duration of the PCI, and may be continued for up to four hours post PCI, at which time the infusion should be either stopped or reduced to a dose of $0.25 \mathrm{mg} / \mathrm{kg} / \mathrm{hr}$ for up to 12 hours at the discretion of the investigator. Dose adjustments may be required according to drug labelling (i.e., renal dysfunction). Bivalirudin, when used instead of heparin with optional glycoprotein IIb/IIIa (GP IIb/IIIa) inhibitors, has consistently demonstrated a reduction in protocol-defined major and minor bleeding ${ }^{27}$. The use of GP IIb/IIIa inhibitors in the GLOBAL LEADERS trial should be limited to bail-out situations only (i.e., no-reflow phenomena, giant thrombus). The use of unfractionated heparin (up to an arbitrary set maximum of 4,000 IU) during the index diagnostic angiogram is left to the discretion of the investigator.

The stent device(s) that will be used during the index procedure (including staging) belong to the BioMatrix ${ }^{\mathrm{TM}}$ drug-eluting stent family (BES; Biosensors Europe SA, Morges, Switzerland) and are CE-marked and commercially available. The Biolimus A9тм/

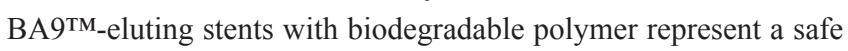

and effective alternative to the sirolimus-eluting stents with durable polymer in patients with on- and off-label indications ${ }^{28}$.

In the event of an intercurrent repeat intervention, for reasons beyond definite stent thrombosis and STEMI, the physician should adhere to the study stent and treatment strategy including one month of concomitant ASA $\leq 100 \mathrm{mg}$ post PCI (including the repeat and unplanned procedures) in the ticagrelor monotherapy arm.

\section{Study endpoints}

The trial endpoints are listed in Table 3 . The primary outcome is the composite of investigator-reported all-cause mortality or non-fatal, new Q-wave myocardial infarction (MI) identified by an independent ECG core laboratory (Cardialysis, Rotterdam, The Netherlands) at two years post randomisation. The rationale for choosing this endpoint is to have an unbiased estimate of the effect regarding irreversible organ damage. All-cause mortality is an objective endpoint and can be readily ascertained with minimal bias or need for adjudication. Similarly, the appearance of new Q-waves on 12-lead electrocardiography (Minnesota Code) following PCI and myocardial infarction is an objective and independent predictor of future mortality $^{29}$. A new left bundle branch block associated with an MI will be considered equivalent to a new Q-wave.

Table 3. GLOBAL LEADERS endpoints.

\begin{tabular}{|l|l|}
\hline Primary & $\begin{array}{l}\text { All-cause death or non-fatal, new Q-wave } \\
\text { myocardial infarction. }\end{array}$ \\
\hline Key secondary & $\begin{array}{l}\text { Investigator-reported (IR) BARC class } 4 \text { or } 5 \\
\text { bleeding events. }\end{array}$ \\
\hline \multirow{3}{*}{ Other } & $\begin{array}{l}\text { The composite of all-cause death, investigator- } \\
\text { reported (IR) non-fatal stroke, IR myocardial } \\
\text { infarction, IR coronary revascularisation. }\end{array}$ \\
\cline { 2 - 3 } & IR non-fatal stroke. \\
\cline { 2 - 3 } & IR myocardial infarction. \\
\cline { 2 - 3 } & IR coronary revascularisation. \\
\cline { 2 - 3 } & $\begin{array}{l}\text { IR definite stent thrombosis according to the } \\
\text { Academic Research Consortium definitions }\end{array}$ \\
\hline
\end{tabular}

The key safety variable is any investigator-reported Bleeding Academic Research Consortium (BARC) class 3 or 5 bleeding (Online Table 1) ${ }^{31}$. BARC consensus definitions have recently been validated post PCI. BARC class 3 or 5 events are independently associated with increased one-year mortality to an extent comparable to that provided by the TIMI criteria ${ }^{32}$. An independent medical reviewer will check the reported endpoint events for validity.

\section{Statistics}

The assumptions regarding event rate for the composite of allcause mortality and Q-wave MI in the reference strategy arm are based on actual data from the BES arm in the LEADERS trial at two years after the index procedure (Online Table 2). With an expected event rate of $5.0 \%$ within the reference treatment strategy arm at two years and a two-sided type I error of 5\%, we estimate that a sample size of 8,000 patients per arm will provide $84 \%$ 
power to detect a $20 \%$ relative risk reduction and $92 \%$ power to detect a $22.5 \%$ relative risk reduction of the experimental treatment strategy compared with the reference treatment strategy.

Analysis of the primary composite and secondary endpoints will be performed according to the intention-to-treat principle of all randomised patients as time-to-first-event. The primary and all secondary endpoints will be analysed using the Mantel-Cox method accompanied by the log-rank test to calculate corresponding p-values. Corresponding survival curves will be constructed using Kaplan-Meier estimates. Patients start being at risk on the day of their index PCI, or, if no PCI was performed, on the day of randomisation. Per-protocol analyses of the primary composite effectiveness endpoint and secondary safety endpoint will be performed as sensitivity analyses. To evaluate for consistency of results among subgroups of interest, exploratory subgroup analyses are pre-specified (Online Appendix 1).

Landmark analyses will be performed according to two prespecified landmark points at 30 days and at one year (365 days), with RR calculated separately for events up to the landmark point and for events occurring after the landmark point up to two years. For each type of event, patients will be censored at the time of the first event: a patient who experienced an event contributing to the primary composite endpoint during the first year, for example, will be censored at the time of the event and excluded from the analysis of subsequent years after the landmark point. Landmark analyses will be accompanied by a test for interaction between treatment effect and time (before versus after the landmark point).

Demographics, baseline (including prior and current medications) and procedural characteristics will be described using counts and percentages if categorical, and means and SD, if continuous. P-values for procedural characteristics on patient-level data will be computed using chi-square and Fisher's exact tests for categorical variables, t-tests for continuous variables, and Wilcoxon's MannWhitney U tests for non-symmetrically distributed continuous variables. P-values for procedural characteristics on lesion-level data will be computed using generalised linear mixed models. In each model a random effect of patient identifier will account for multiple lesions measured within patients.

\section{Present status}

The first patient in the GLOBAL LEADERS trial was enrolled in June 2013. By March 1, 2015, 10,000 patients had been enrolled. The end of enrolment is projected for September 2015.

\section{Conclusion}

The GLOBAL LEADERS trial includes minimally selected, consecutive patients undergoing PCI with bivalirudin and unrestricted use of BES. The protocol also allows for patients exposed to clopidogrel/prasugrel, both as maintenance treatment and loading dose. Therefore, the trial will reflect the full spectrum of patients managed in routine PCI practice with different clinical presentations (with the exception of thrombolytic and anticoagulant therapy at the time of randomisation), and will provide a pivotal comparison of the efficacy and safety of a short course of ticagrelor plus aspirin followed by 23-month ticagrelor monotherapy versus the contemporary standard-of-care DAPT regimen.

The GLOBAL LEADERS trial challenges the concept that, against the background of ticagrelor, ongoing aspirin treatment, beyond the initial one month time period of high stent thrombosis risk, is well serving. More potent, more consistent antiplatelet inhibition with ticagrelor may be a better foundation for longterm antiplatelet therapy compared to aspirin in at-risk patients. GLOBAL LEADERS will also provide preliminary 30-day efficacy and safety data on a randomised comparison of ticagrelor plus low-dose aspirin versus clopidogrel and aspirin following DES use in a cohort of stable CAD patients. The GLOBAL LEADERS trial may pave the way for future studies of ticagrelor as antiplatelet monotherapy across a wide spectrum of patients with CAD and is the first large-scale study on ticagrelor in elective stenting.

\section{Impact on daily practice}

The GLOBAL LEADERS trial challenges the concept that, against the background of ticagrelor, ongoing aspirin treatment beyond the initial one-month time period of high stent thrombosis risk, is well serving. The GLOBAL LEADERS trial may pave the way for future studies of ticagrelor as antiplatelet monotherapy across a wide spectrum of patients with coronary artery disease and is the first large-scale study on ticagrelor in elective coronary artery stenting.

\section{Guest Editor}

This paper was guest edited by George Dangas, MD, PhD; Division of Cardiology, Mount Sinai Medical Center, New York, NY, USA; Cardiovascular Research Foundation, New York, NY, USA.

\section{Conflict of interest statement}

C. Hamm discloses the following relationships: advisory and speakers honoraria from AstraZeneca. P. Jüni received research grants to the institution from AstraZeneca, Biotronik, Biosensors International, Eli Lilly and The Medicines Company, and unpaid membership of the steering group of trials funded by AstraZeneca, Biotronik, Biosensors, St. Jude Medical and The Medicines Company. P.W. Serruys declares a research grant (to INSERM U1148) from Sanofi, and Servier; speaking or consulting honoraria from Abbott Laboratories, AstraZeneca, Biotronic, Medtronic, Sino Medical Sciences Technology, Stentys, Svelte Medical Systems, Volcano, unpaid membership of the advisory board of Abbott Vascular, unpaid membership of the steering group of trials funded by Medtronic. P. Steg received research grants (to INSERM U1148) from Sanofi, and Servier; speaking or consulting honoraria from Amarin, AstraZeneca, Bayer, Boehringer-Ingelheim, Bristol-Myers Squibb, CSL Behring, Daiichi-Sankyo, GlaxoSmithKline, Janssen, Lilly, Novartis, Pfizer, Regeneron, Roche, Sanofi, Servier, The Medicines Company; and 
owns stocks from Aterovax. M. Valgimigli received speaking or consulting honoraria from Biosensors, The Medicines Company and AstraZeneca and research grants from AstraZeneca and The Medicines Company. P. Vranckx received speaking or consulting honoraria from Bayer, Daiichi-Sankyo, The Medicines Company and AstraZeneca. S. Windecker received research grants to the institution from Abbott, Boston Scientific, Biotronik, Medtronic. The other authors have no conflicts of interest to declare. The Guest Editor receives speaker honoraria (modest level) from The Medicines Company. His spouse is on the Advisory Board (modest level) of AstraZeneca.

\section{References}

1. Fihn SD, Blankenship JC, Alexander KP, Bittl JA, Byrne JG, Fletcher BJ, Fonarow GC, Lange RA, Levine GN, Maddox TM, Naidu SS, Ohman EM, Smith PK. 2014 ACC/AHA/AATS/PCNA/ SCAI/STS focused update of the guideline for the diagnosis and management of patients with stable ischemic heart disease: a report of the American College of Cardiology/American Heart Association Task Force on Practice Guidelines, and the American Association for Thoracic Surgery, Preventive Cardiovascular Nurses Association, Society for Cardiovascular Angiography and Interventions, and Society of Thoracic Surgeons. Circulation. 2014;130:1749-67.

2. Windecker S, Kolh P, Alfonso F, Collet JP, Cremer J, Falk V, Filippatos G, Hamm C, Head SJ, Jüni P, Kappetein AP, Kastrati A, Knuuti J, Landmesser U, Laufer G, Neumann FJ, Richter DJ, Schauerte P, Sousa Uva M, Stefanini GG, Taggart DP, Torracca L, Valgimigli M, Wijns W, Witkowski A. 2014 ESC/EACTS guidelines on myocardial revascularization. EuroIntervention. 2015;10: 1024-94.

3. Valgimigli M, Campo G, Monti M, Vranckx P, Percoco G, Tumscitz C, Castriota F, Colombo F, Tebaldi M, Fucà G, Kubbajeh M, Cangiano E, Minarelli M, Scalone A, Cavazza C, Frangione A, Borghesi M, Marchesini J, Parrinello G, Ferrari R; Prolonging Dual Antiplatelet Treatment After Grading StentInduced Intimal Hyperplasia Study (PRODIGY) Investigators. Short- versus long-term duration of dual-antiplatelet therapy after coronary stenting: a randomized multicenter trial. Circulation. 2012;125:2015-26.

4. Park SJ, Park DW, Kim YH, Kang SJ, Lee SW, Lee CW, Han KH, Park SW, Yun SC, Lee SG, Rha SW, Seong IW, Jeong MH, Hur SH, Lee NH, Yoon J, Yang JY, Lee BK, Choi YJ, Chung WS, Lim DS, Cheong SS, Kim KS, Chae JK, Nah DY, Jeon DS, Seung KB, Jang JS, Park HS, Lee K. Duration of dual antiplatelet therapy after implantation of drug-eluting stents. $N$ Engl J Med. 2010;362:1374-82.

5. Valgimigli M, Park SJ, Kim HS, Park KW, Park DW, Tricoci P, Ferrante G. Benefits and risks of long-term duration of dual antiplatelet therapy after drug-eluting stenting: a meta-analysis of randomized trials. Int J Cardiol. 2013;168:2579-87.

6. Gwon HC, Hahn JY, Park KW, Song YB, Chae IH, Lim DS, Han KR, Choi JH, Choi SH, Kang HJ, Koo BK, Ahn T, Yoon JH,
Jeong MH, Hong TJ, Chung WY, Choi YJ, Hur SH, Kwon HM, Jeon DW, Kim BO, Park SH, Lee NH, Jeon HK, Jang Y, Kim HS. Six-month versus 12-month dual antiplatelet therapy after implantation of drug-eluting stents: the Efficacy of Xience/Promus Versus Cypher to Reduce Late Loss After Stenting (EXCELLENT) randomized, multicenter study. Circulation. 2012;125:505-13.

7. Mauri L, Kereiakes DJ, Yeh RW, Driscoll-Shempp P, Cutlip DE, Steg PG, Normand SL, Braunwald E, Wiviott SD, Cohen DJ, Holmes DR Jr, Krucoff MW, Hermiller J, Dauerman HL, Simon DI, Kandzari DE, Garratt KN, Lee DP, Pow TK, Ver Lee P, Rinaldi MJ, Massaro JM; DAPT Study Investigators. Twelve or 30 months of dual antiplatelet therapy after drug-eluting stents. N Engl J Med. 2014;371:2155-66.

8. Giustino G, Baber U, Sartori S, Mehran R, Mastoris I, Kini AS, Sharma SK, Pocock SJ, Dangas GD. Duration of dual antiplatelet therapy after drug-eluting stent implantation: a systematic review and meta-analysis of randomized controlled trials. $\mathrm{J} \mathrm{Am}$ Coll Cardiol. 2015;65:1298-310.

9. Navarese EP, Andreotti F, Schulze V, Kołodziejczak M, Buffon A, Brouwer M, Costa F, Kowalewski M, Parati G, Lip GY, Kelm M, Valgimigli M. Optimal duration of dual antiplatelet therapy after percutaneous coronary intervention with drug eluting stents: meta-analysis of randomised controlled trials. BMJ. 2015; 350:h1618.

10. Gurbel PA, Bliden KP, Hayes KM, Yoho JA, Herzog WR, Tantry US. The relation of dosing to clopidogrel responsiveness and the incidence of high post-treatment platelet aggregation in patients undergoing coronary stenting. $J$ Am Coll Cardiol. 2005;45: 1392-6.

11. Collet JP, Hulot JS, Pena A, Esteve JB, Silvain J, Payot L, Brugier D, Cayla G, Beygui F, Bensimon G, Funck-Brentano C, Montalescot G. Cytochrome P450 2C19 polymorphism in young patients treated with clopidogrel after myocardial infarction: a cohort study. Lancet. 2009;373:309-17.

12. Mega JL, Close SL, Wiviott SD, Shen L, Hockett RD, Brandt JT, Walker JR, Antman EM, Macias W, Braunwald E, Sabatine MS. Cytochrome P-450 polymorphisms and response to clopidogrel. N Engl J Med. 2009;360:354-62.

13. Bonello L, Camoin-Jau L, Arques S, Boyer C, Panagides D, Wittenberg O, Simeoni MC, Barragan P, Dignat-George F, Paganelli F. Adjusted clopidogrel loading doses according to vasodilator-stimulated phosphoprotein phosphorylation index decrease rate of major adverse cardiovascular events in patients with clopidogrel resistance: a multicenter randomized prospective study. J Am Coll Cardiol. 2008;51:1404-11.

14. Wiviott SD, Braunwald E, McCabe CH, Montalescot G, Ruzyllo W, Gottlieb S, Neumann FJ, Ardissino D, De Servi S, Murphy SA, Riesmeyer J, Weerakkody G, Gibson CM, Antman EM; TRITON-TIMI 38 Investigators. Prasugrel versus clopidogrel in patients with acute coronary syndromes. $N$ Engl $J$ Med. 2007;357:2001-15.

15. Wallentin L, Becker RC, BudajA, Cannon CP, Emanuelsson H, Held C, Horrow J, Husted S, James S, Katus H, Mahaffey KW, 
Scirica BM, Skene A, Steg PG, Storey RF, Harrington RA; PLATO Investigators, Freij A, Thorsén M. Ticagrelor versus clopidogrel in patients with acute coronary syndromes. $N$ Engl $J$ Med. 2009;361:1045-57.

16. Cannon CP, Harrington RA, James S, Ardissino D, Becker RC, Emanuelsson H, Husted S, Katus H, Keltai M, Khurmi NS, Kontny F, Lewis BS, Steg PG, Storey RF, Wojdyla D, Wallentin L; PLATelet inhibition and patient Outcomes Investigators. Comparison of ticagrelor with clopidogrel in patients with a planned invasive strategy for acute coronary syndromes (PLATO): a randomised double-blind study. Lancet. 2010;375:283-93.

17. Husted S, Emanuelsson H, Heptinstall S, Sandset PM, Wickens M, Peters G. Pharmacodynamics, pharmacokinetics, and safety of the oral reversible $\mathrm{P}_{2} \mathrm{Y}_{12}$ antagonist AZD6140 with aspirin in patients with atherosclerosis: a double-blind comparison to clopidogrel with aspirin. Eur Heart J. 2006;27:1038-47.

18. Gaglia MA, Waksman R. Overview of the 2010 Food and Drug Administration. Cardiovascular and Renal Drugs Advisory Committee meeting regarding ticagrelor. Circulation. 2011;123:451-6.

19. Mahaffey KW, Wojdyla DM, Carroll K, Becker RC, Storey RF, Angiolillo DJ, Held C, Cannon CP, James S, Pieper KS, Horrow J, Harrington RA, Wallentin L; for the PLATO Investigators. Ticagrelor compared with clopidogrel by geographic region in the Platelet Inhibition and Patient Outcomes (PLATO) trial. Circulation. 2011;124:544-54.

20. Armstrong PC, Leadbeater PD, Chan MV, Kirkby NS, Jakubowski JA, Mitchell JA, Warner TD. In the presence of strong P2 $Y_{12}$ receptor blockade, aspirin provides little additional inhibition of platelet aggregation. J Thromb Haemost. 2011;9:552-61.

21. Stone GW, Maehara A, Lansky AJ, de Bruyne B, Cristea E, Mintz GS, Mehran R, McPherson J, Farhat N, Marso SP, Parise H, Templin B, White R, Zhang Z, Serruys PW; PROSPECT Investigators. A prospective natural-history study of coronary atherosclerosis. N Engl J Med. 2011;364:226-35.

22. Silber S, Windecker S, Vranckx P, Serruys PW; RESOLUTE All Comers investigators. Unrestricted randomised use of two new generation drug-eluting coronary stents: 2 -year patient-related versus stent-related outcomes from the RESOLUTE All Comers trial. Lancet. 2011;377:1241-7.

23. CAPRIE Steering Committee. A randomised, blinded, trial of clopidogrel versus aspirin in patients at risk of ischaemic events (CAPRIE). CAPRIE Steering Committee. Lancet. 1996;348:1329-39.

24. Bonaca MP, Bhatt DL, Cohen M, Steg PG, Storey RF, Jensen EC, Magnani G, Bansilal S, Fish MP, Im K, Bengtsson O, Ophuis TO, Budaj A, Theroux P, Ruda M, Hamm C, Goto S, Spinar J, Nicolau JC, Kiss RG, Murphy SA, Wiviott SD, Held P, Braunwald E, Sabatine MS; PEGASUS-TIMI 54 Steering Committee and Investigators. Long-term use of ticagrelor in patients with prior myocardial infarction. N Engl J Med. 2015;372: 1791-800.

25. Serruys PW, Onuma Y, Garg S, Sarno G, van den Brand M, Kappetein AP, Van Dyck N, Mack M, Holmes D, Feldman T, Morice MC, Colombo A, Bass E, Leadley K, Dawkins KD, van
Es GA, Morel MA, Mohr FW. Assessment of the SYNTAX score in the Syntax study. EuroIntervention. 2009;5:50-6.

26. Eagle KA, Lim MJ, Dabbous OH, Pieper KS, Goldberg RJ, Van de Werf F, Goodman SG, Granger CB, Steg PG, Gore JM, Budaj A, Avezum A, Flather MD, Fox KA; GRACE Investigators. A validated prediction model for all forms of acute coronary syndrome: estimating the risk of 6-month postdischarge death in an international registry. JAMA. 2004;291:2727-33.

27. Verheugt FW, Steinhubl SR, Hamon M, Darius H, Steg PG, Valgimigli M, Marso SP, Rao SV, Gershlick AH, Lincoff AM, Mehran R, Stone GW. Incidence, prognostic impact, and influence of antithrombotic therapy on access and nonaccess site bleeding in percutaneous coronary intervention. JACC Cardiovasc Interv. 2011;4:191-7.

28. Windecker S, Serruys PW, Wandel S, Buszman P, Trznadel S, Linke A, Lenk K, Ischinger T, Klauss V, Eberli F, Corti R, Wijns W, Morice MC, di Mario C, Davies S, van Geuns RJ, Eerdmans P, van Es GA, Meier B, Jüni P. Biolimus-eluting stent with biodegradable polymer versus sirolimus-eluting stent with durable polymer for coronary revascularisation (LEADERS): a randomised non-inferiority trial. Lancet. 2008;372:1163-73.

29. Horan LG, Flowers NC, Johnson JC. Significance of the diagnostic Q wave of myocardial 898 infarction. Circulation. 1971;43:428-36.

30. Cutlip DE, Windecker S, Mehran R, Boam A, Cohen DJ, van Es GA, Steg PG, Morel MA, Mauri L, Vranckx P, McFadden E, Lansky A, Hamon M, Krucoff MW, Serruys PW; Academic Research Consortium. Clinical end points in coronary stent trials: a case for standardized definitions. Circulation. 2007;115: 2344-51.

31. Mehran R, Rao SV, Bhatt DL, Gibson CM, Caixeta A, Eikelboom J, Kaul S, Wiviott SD, Menon V, Nikolsky E, Serebruany V, Valgimigli M, Vranckx P, Taggart D, Sabik JF, Cutlip DE, Krucoff MW, Ohman EM, Steg PG, White H. Standardized bleeding definitions for cardiovascular clinical trials: a consensus report from the Bleeding Academic Research Consortium. Circulation. 2011;123:2736-47.

32. Vranckx P, Leonardi S, Tebaldi M, Biscaglia S, Parrinello G, Rao SV, Mehran R, Valgimigli M. Prospective validation of the Bleeding Academic Research Consortium classification in the allcomer PRODIGY trial. Eur Heart J. 2014;35:2524-9.

\section{Supplementary data}

Online Appendix 1. Pre-specified subgroup analyses of the primary endpoint according to specific angiographic and clinical risk estimates.

Online Appendix 2. Steering Committee.

Online Table 1. BARC class 3 and 5 bleeding criteria. Online Table 2. Power calculation.

The supplementary data are published online at: http://www.pcronline.com/

eurointervention/107th_issue/204 


\section{Supplementary data}

\section{Online Appendix 1}

\section{PRE-SPECIFIED SUBGROUP ANALYSES OF THE PRIMARY ENDPOINT ACCORDING TO SPECIFIC ANGIOGRAPHIC AND CLINICAL RISK ESTIMATES}

We will check for interactions with treatment regimen towards cardiovascular efficacy and safety outcomes on the following items:

\section{CLINICAL PRESENTATION}

1. Treatment regimen in relation to clinical presentation (acute coronary syndrome vs. stable, elective) overall.

2. Treatment regimen in relation to clinical presentation (ST-segment elevation ACS, non-STE ACS) overall.

3. Treatment regimen in relation to clinical presentation and angiographic risk profile (ST ACS vs. SYNTAX score >8) overall.

4. Treatment regimen in stable patients up to 30 days, 30 days to end of trial (30-day landmark).

5. Treatment regimen in relation to ECG changes at presentation.

\section{CONCOMITANT DISEASE/BASELINE RISK FACTORS}

6. Treatment regimen in relation to renal function (and dialysis) at time of randomisation.

7. Treatment regimen in relation to diabetes (type $1 \& 2$ ) status at randomisation.

8. Treatment regimen in relation to weight (body mass index $\geq 27$ ) at the time of randomisation.

9. Treatment regimen in relation to age at the time of randomisation.

10. Treatment regimen in relation to gender.

11. Treatment regimen in relation to history of cardiovascular (cardiac, peripheral, or combined) disease (including coronary artery bypass grafting).

12. Treatment regimen in relation to history of prior stroke or transient ischaemic attack.

13. Treatment regimen in relation to the GRACE risk score at admission.

14. Treatment regimen in relation to the SYNTAX score (I \& II) at admission. Including: value of incorporating baseline ECG changes into the SYNTAX I and II scores. Including: impact of residual (after PCI) SYNTAX score with respect to treatment effect and outcomes.

15. Impact of CRUSADE and or ACUITY bleeding scores in risk stratifying bleeding and ischaemic events and its interaction with treatment strategies.

\section{GEOGRAPHIC REGION}

16. Treatment regimen in relation to geographic region (regionby-treatment interaction) prospectively defined as South America, Canada, Europe, Asia.

\section{TREATMENT ELEMENTS}

DRUG

17. Treatment regimen in relation to the access site used during the index procedure.

18. Treatment regimen in relation to periprocedural anticoagulation. Including: safety and efficacy of switching strategies on anticoagulation before and during the procedure.

19. Treatment regimen and outcome in patients in need of CABG.

20. Treatment regimen and outcome in patients with non-cardiac surgery.

21. Treatment regimen in relation to previous exposure to aspirin and/or $\mathrm{P}_{2} \mathrm{Y}_{12}$ receptor blocker (vs. naïve patients). The ONSET study. Including: safety and efficacy of switching strategies with respect to $\mathrm{P} 2 \mathrm{Y}_{12}$ inhibition before PCI.

22. Treatment regimen in relation to proton pump inhibitor use.

23. Treatment regimen in relation to post-procedure anticoagulation.

\section{STENT PROCEDURE}

24. Treatment regimen in relation to staged procedures.

25. Treatment regimen in relation to specific lesion subsets including:
a. Left main
b. Bifurcations

\section{ANALYSIS}

26. Treatment regimen with a landmark analysis at 12 months.

27. BARC bleeding analysis including case fatality hazard.

28. OFFSET trial. Treatment regimen in relation to prolonged follow-up.

29. Treatment regimen in relation to repeat events (including bleeding).

\section{Online Appendix 2 STEERING COMMITTEE VOTING:}

P.W. Serruys (chair)

S. Windecker (co-principal investigator)

M. Valgimigli (co-principal investigator)

P. Vranckx (co-principal investigator)

P.G. Steg

C. Hamm

G.A. van Es (ECRI)

P. Jüni (statistician)

\section{CORE LABORATORY}

\section{ANGIOGRAPHY:}

An independent angiographic core laboratory, located at Cardialysis, Rotterdam, The Netherlands, will analyse all diagnostic angiograms 
and define the SYNTAX score blinded to the therapy. Members of the angiographic core laboratory are not involved as investigators or co-investigators in this study.

\section{ECG:}

ECGs will be collected according to the schedule of investigations and will be assessed by an independent core laboratory, located at Cardialysis, Rotterdam, The Netherlands.

\section{DATA SAFETY AND MONITORING BOARD:}

F.W.A. Verheugt, Onze Lieve Vrouw Gasthuis, Amsterdam, The Netherlands (Chairman)

J.G.P.Tijssen, Academic Medical Center, Amsterdam,

The Netherlands (Biostatistician)

L. Mauri, Brigham and Women's Hospital, Boston, USA.

Online Table 1. BARC class 3 and 5 bleeding criteria.

\begin{tabular}{|c|c|}
\hline \multirow[t]{2}{*}{ Type 3A } & $\begin{array}{l}\text { Overt bleeding plus haemoglobin drop of } 3 \text { to }<5 \mathrm{~g} / \mathrm{dL}^{*} \\
\text { (provided haemoglobin drop is related to bleed) }\end{array}$ \\
\hline & Any transfusion with overt bleeding \\
\hline \multirow[t]{4}{*}{ Type 3B } & $\begin{array}{l}\text { Overt bleeding plus haemoglobin drop } \geq 5 \mathrm{~g} / \mathrm{dL}^{*} \\
\text { (provided haemoglobin drop is related to bleed) }\end{array}$ \\
\hline & Cardiac tamponade \\
\hline & $\begin{array}{l}\text { Bleeding requiring surgical intervention for control } \\
\text { (excluding dental/nasal/skin/haemorrhoid) }\end{array}$ \\
\hline & Bleeding requiring intravenous vasoactive agents \\
\hline \multirow[t]{3}{*}{ Type 3C } & $\begin{array}{l}\text { Intracranial haemorrhage (does not include micro-bleeds } \\
\text { or haemorrhagic transformation, does include intra-spinal) }\end{array}$ \\
\hline & $\begin{array}{l}\text { Subcategories confirmed by autopsy or imaging or } \\
\text { lumbar puncture }\end{array}$ \\
\hline & Intraocular bleed compromising vision \\
\hline Type 5A & $\begin{array}{l}\text { Probable fatal bleeding: no autopsy or imaging } \\
\text { confirmation but clinically suspicious }\end{array}$ \\
\hline Type 5B & $\begin{array}{l}\text { Definite fatal bleeding; overt bleeding or autopsy or } \\
\text { imaging confirmation }\end{array}$ \\
\hline \multicolumn{2}{|c|}{$\begin{array}{l}\text { * Corrected for transfusion ( } 1 \mathrm{U} \text { packed red blood cells or } 1 \mathrm{U} \text { whole } \\
\text { blood=1 g/dL haemoglobin). }\end{array}$} \\
\hline
\end{tabular}

\section{BLINDED INDEPENDENT MEDICAL REVISOR:}

E. McFadden, Cork University Hospital, Cork, Ireland.

\section{DATA MONITORING:}

CARDIALYSIS

92 Westblaak, 3012 KM Rotterdam, The Netherlands.

\section{THEOREM}

1016 West Ninth Avenue, King of Prussia, PA, 19406, USA.

\section{SPONSOR:}

The European Cardiovascular Research Institute (ECRI; www.ECRI-trials.com)

\section{Online Table 2. Power calculation.}

With an expected event rate of $5.0 \%$ within the experimental treatment strategy at two years and a two-sided type I error of $5 \%$, we estimate that the sample size of 8,000 patients per arm will provide $84 \%$ power to detect a $20 \%$ relative risk reduction and $92 \%$ power to detect a $22.5 \%$ relative risk reduction of the experimental treatment strategy as compared with the control treatment strategy.

The table below presents the power according to relative risk reductions of $17.5 \%, 20 \%, 22.5 \%$, and $25 \%$, respectively:

\begin{tabular}{|c|c|c|c|}
\hline $\begin{array}{c}\text { Treatment effect } \\
(\%)\end{array}$ & Power (\%) & $\begin{array}{c}\text { Attrition rate } \\
(\%)\end{array}$ & $\begin{array}{c}\text { Total sample } \\
\text { size }\end{array}$ \\
\hline 17.5 & 73 & 4 & 16,000 \\
\hline 20.0 & 84 & 4 & 16,000 \\
\hline 22.5 & 92 & 4 & 16,000 \\
\hline 25.0 & 96 & 4 & 16,000 \\
\hline
\end{tabular}

